\title{
ANALISIS EFISIENSI UNIT PENANGKAPAN PUKAT CINCIN DI PELABUHAN PERIKANAN PANTAI LAMPULO BANDA ACEH
}

\section{(EFFICIENCY ANALYSIS OF PURSE SEINE FISHING UNIT COASTAL FISHING PORT LAMPULO BANDA ACEH)}

\author{
Ratna Mutia Aprilla ${ }^{1,2}$, Mustaruddin², Eko Sri Wiyono², Nimmi Zulbainarni ${ }^{2}$ \\ ${ }^{1}$ Corresponding author \\ ${ }^{2}$ Program Studi Sistem dan Pemodelan Perikanan Tangkap \\ E-mail: Aprilla_mutia88@yahoo.com
}

\begin{abstract}
Measurement of productivity, technical and economic efficiency are the key indicators in assessing the ability of purse seine fishing unit based in Fishing Port Lampulo, Banda Aceh. The objectives of this study are to analyse of productivity and effeciency of purse seine units. There were some factors that support the production catches of purse seine fishing unit such as the size of the vessel, engine power, length of nets, net height, number of crew, fuel, number of light, the amount of ice, freshwater and supply costs were analyzed using the Cobb-Douglas approach. Productivitiy calculation had done by using the approach of purse seine catches for the year divided by amount of Gross Tonnage and catching trip. The results showed the highest productivity per trip was 1.86 tons/trip in 2012 and the highest productivity per GT was 9.97 tons/GT in 2011. Production factors which significantly affect to catch of purse seine were engine power, net height, number of crew, number of lights and supply cost. Analysis of the technical efficiency towards 54 vessel showed that the vessel engines power production factors (-0.432), the number of crew (-1.116), and number of lights $(-0.148)$ the value of its production elasticity were inefficient $(\mathrm{E} p<0)$, whereas purse seine net height $(0.467)$ was at the rational production stage $(0<E p<1)$ and factor costs of production supplies (2.181) was efficient (Ep>1) which means inefficient use of production factor. Economic efficiency for the use of production factor wass inefficient because the value of NPMxi/PXI $<1$.
\end{abstract}

Keywords: Purse seine, production factors, productivity, efficiency

\begin{abstract}
ABSTRAK
Pengukuran produktivitas, efisiensi secara teknis dan ekonomi merupakan indikator utama dalam menilai kemampuan usaha dari unit penangkapan. Tujuan penelitian ini adalah menghitung produktivitas unit penangkapan pukat cincin, memformulasikan faktor-faktor produksi yang berperan terhadap hasil tangkapan dan hubungannya terhadap hasil tangkapan unit penangkapan pukat cincin, serta menghitung efisiensi dari penggunaan faktor produksi unit penangkapan pukat cincin yang berbasis di Pelabuhan Perikanan Pantai (PPP) Lampulo. Faktor produksi yang menunjang hasil tangkapan unit penangkapan pukat cincin seperti ukuran kapal, daya mesin kapal, panjang jaring, tinggi jaring, jumlah awak kapal, BBM, jumlah lampu, jumlah es, jumlah air tawar dan biaya perbekalan dianalisis menggunakan pendekatan Cobb-Douglas. Perhitungan produktivitas dilakukan dengan pendekatan rata-rata hasil tangkapan pukat cincin selama setahun dibagi dengan besarnya Gross Tonage dan trip penangkapan. Hasil penelitian menunjukkan produktivitas per trip tertinggi yaitu 1.86 ton/trip pada tahun 2012 dan produktivitas per GT tertinggi yaitu 9.97 ton/GT pada tahun 2011. Persamaan fungsi produksi Cobb-Douglas unit penangkapan pukat cincin di PPP Lampulo yaitu $\operatorname{LnY}=-18.875-0.432 \operatorname{LnX} 2+0.467 \operatorname{LnX} 4-1.116 \operatorname{LnX} 5-0.184 \operatorname{LnX} 7+2.181 \operatorname{LnX} 10$, dengan nilai $\mathrm{R}^{2}=$ 0.727. Analisis efisiensi teknis pada 54 kapal menunjukkan penggunaan faktor produksi daya mesin kapal (0.432), jumlah awak kapal (-1.116), dan jumlah lampu (-0.184) nilai elastisitas produksinya sudah negatif $(E p<0)$ yang menunjukkan penggunaan faktor produksi sudah tidak efisien, sedangkan faktor produksi dari tinggi jaring (0.467) berada pada tahap produksi rasional karena berada antara $0<$ Ep $<1$ dan faktor produksi biaya perbekalan (2.181) nilai Ep $>1$ yang artinya penggunaan faktor produksi belum efisien. Efisiensi ekonomis penggunaan variabel faktor produksi tersebut tidak efisien karena nilai NPMxi/BKMxi $<1$.
\end{abstract}

Kata Kunci: Pukat cincin, faktor produksi, produktivitas, efisiensi

\section{PENDAHULUAN}

Usaha perikanan pukat cincin saat ini sangat diminati oleh para nelayan yang berbasis di Pelabuhan Perikanan
Pantai (PPP) Lampulo. Hal ini terlihat dari produksi perikanan laut di Kota Banda Aceh yang hampir semuanya (76\%) ditopang oleh produksi dari armada penangkapan pukat cincin selama lima 
tahun terakhir (2007-2011), peningkatan produksi ini seiring dengan bertambahnya jumlah unit penangkapan pukat cincin (DKP Provinsi Aceh, 2012). Nelayan beranggapan bahwa usaha perikanan pukat cincin memiliki peluang yang cukup besar dalam memanfaatkan sumberdaya perikanan yang ada dalam mencapai keuntungan maksimum, namun ada beberapa permasalahan yang dihadapi oleh nelayan pukat cincin yang berbasis di Lampulo dalam menjaga produktivitas penangkapan dan meningkatkan efisiensi dari penggunaan faktor produksi usaha perikanan.

Permasalahan yang dihadapi antara lain daerah operasi penangkapan bergerak semakin jauh dari pantai, yang tentu saja meningkatkan biaya operasional penangkapan. Nelayan sangat bergantung pada faktor-faktor produksi dalam melaksanakan kegiatannya, yang pada beberapa tahun terakhir faktor produksi mengalami kenaikan harga sehingga dengan hasil tangkapan yang cenderung tidak pasti, diduga menyebabkan pendapatan para nelayan cenderung tidak pasti. Pendapatan nelayan di sini sangat ditentukan oleh besar kecilnya produksi yang dihasilkan mengingat pemberian intensif bagi tenaga kerja (ABK) tidak berdasarkan pada sistem penggajian melainkan dengan sistem bagi hasil yang diterapkan. Kenyataan dilapangan menunjukkan nelayan dalam mendapatkan hasil jualnya relatif sedikit dikarenakan biaya operasional yang harus dikeluarkan sangat besar sehingga mengurangi pendapatan. Penggunaan alat tangkap perikanan yang sembarangan dan tidak memperhatikan aspek biologis ikut berperan dalam penurunan hasil tangkapan merupakan suatu cerminan permasalahan yang dihadapi nelayan pukat cincin dalam menjaga produktivitas penangkapan. Perubahan upaya penangkapan yang dilakukan nelayan pukat cincin seperti memperbesar ukuran kapal berpengaruh terhadap penanganan dan daya tampung dari kapal.

Keberhasilan penangkapan sangat dipengaruhi oleh tingkat upaya penangkapan yang dilakukan oleh nelayan pukat cincin dalam penggunaan faktorfaktor produksi. McCluskey dan Lewison (2008) menyatakan bahwa upaya penangkapan merupakan ukuran untuk menghasilkan sejumlah hasil tangkapan atau ukuran produktivitas dari unit penangkapan ikan. Setiap armada pukat cincin di PPP Lampulo memiliki keragaman faktor produksi yang tentunya akan berpengaruh terhadap produksi yang dihasilkan. Hal ini diduga menyebabkan banyak dari para nelayan terus meningkatkan penggunaan faktor-faktor produksi tersebut tanpa memperhatikan tingkat efisiensi dari faktor tersebut. Penggunaan faktor produksi yang tidak sesuai dapat menjadikan faktor tersebut tidak efisien. Oleh karena itu penggunaan faktor produksi secara efisien dalam operasi penangkapan ikan sangat diperlukan sehingga hasil dan pendapatan maksimal dapat diperoleh oleh nelayan.

Tujuan penelitian ini adalah (1) Menghitung produktivitas unit penangkapan pukat cincin yang berbasis di PPP Lampulo, (2) Memformulasikan faktorfaktor produksi yang berperan terhadap produksi dan hubungannya terhadap produksi unit penangkapan pukat cincin yang berbasis di PPP Lampulo dan (3) Menghitung efisiensi dari penggunaan faktor produksi unit penangkapan pukat cincin yang berbasis di PPP Lampulo.

\section{METODOLOGI}

\subsection{Tempat dan Waktu}

Lokasi penelitian terletak di Pelabuhan Perikanan Pantai Lampulo Kota Banda Aceh. Penelitian ini dilaksanakan dari Januari sampai dengan Februari 2013 dan didukung dengan data produksi.

\subsection{Metode Penelitian}

Metode yang digunakan dalam penelitian ini adalah metode survei terhadap unit penangkapan pukat cincin harian yang berbasis di PPP Lampulo, Banda Aceh.

\subsection{Metode Pengumpulan Data}

Data yang dikumpulkan berupa data primer dan data sekunder. Data primer terdiri dari hasil tangkapan per trip penangkapan, komposisi hasil tangkapan dan penggunaan faktor-faktor produksi/trip penangkapan selama bulan penelitian. Data diperoleh berdasarkan observasi dan wawancara langsung terhadap nelayan dan pelaku usaha perikanan pukat cincin yang 
terkait. Data sekunder hasil tangkapan juga dikumpulkan secara time series tahunan dari PPP Lampulo mulai tahun 2010-2012. Selain data hasil tangkapan diperlukan juga data trip penangkapan dan ukuran kapal pukat cincin yang digunakan nelayan pukat cincin harian dari tahun 2010-2012. Data diperoleh dari lembaga atau instansi yang terkait dalam penelitian yaitu UPTD Lampulo dan Dinas Kelautan dan Perikanan Provinsi Aceh.

\subsection{Teknik Pengumpulan Data}

Teknik pengambilan sampel dilakukan dengan menggunakan sensus yaitu seluruh populasi dijadikan sampel (Sugiyono, 2007). Berdasarkan data UPTD PPP Lampulo (2012), terdapat 54 unit pukat cincin harian yang berbasis di PPP lampulo dalam kurun waktu Januari-Februari 2013. Oleh karena itu, sebanyak 54 unit pukat cincin yang dijadikan sebagai objek penelitian.

\subsection{Metode Analisis}

\section{(1) Analisis Produktivitas Pukat Cincin}

Nilai produktivitas pada penelitian ini dapat diketahui dengan menghitung rata-rata hasil tangkapan kapal pukat cincin selama setahun dan upaya penangkapan berupa trip penangkapan dan ukuran kapal yang digunakan. Upaya penangkapan merupakan aktivitas penangkapan yang dilakukan pada suatu daerah penangkapan tertentu dalam suatu satuan waktu dengan menggunakan jenis alat tangkap tertentu, ukuran kapal, memiliki satuan hari melaut (Iriana et al, 2012).

Produktivitas dalam trip $=$ $\frac{\text { rata-rata produksi }}{\text { rata-rata trip penangkapan }}$ (ton/trip/tahun)

Produktivitas dalam GT $=$ rata-rata produksi

rata-rata rukuran kapal penangkapan $(\operatorname{ton} / \mathrm{GT} /$ tahun)

\section{(2) Analisis Faktor Produksi}

Analisis faktor produksi adalah analisis yang menjelaskan hubungan antara produksi dengan faktor-faktor produksi yang mempengaruhinya. Menurut Soekartawi (2003), untuk mengamati pengaruh beberapa faktor produksi tertentu terhadap output secara kese- luruhan dalam keadaan sebenarnya adalah tidak mungkin. Oleh karena itu hubungan antara faktor produksi dengan output perlu disederhanakan dalam bentuk suatu model. Hubungan kuantitatif antara faktor-faktor produksi (ukuran kapal $\left(\mathrm{X}_{1}\right)$, daya mesin kapal $\left(\mathrm{X}_{2}\right)$, panjang jaring $\left(\mathrm{X}_{3}\right)$, tinggi jaring $\left(\mathrm{X}_{4}\right)$, jumlah awak kapal $\left(\mathrm{X}_{5}\right)$, jumlah $\mathrm{BBM}$ $\left(\mathrm{X}_{6}\right)$, jumlah lampu $\left(\mathrm{X}_{7}\right)$, jumlah es $\left(\mathrm{X}_{8}\right)$, penggunaan air tawar $\left(\mathrm{X}_{9}\right)$, dan perbekalan $\left(\mathrm{X}_{10}\right)$ ) dengan produksi dapat dihitung berdasarkan fungsi produksi Cobb-Douglas. Model Cobb-Douglas/Logaritma adalah sebagai berikut:

$$
Y=a X_{1}{ }^{b_{1}} X_{2}{ }^{b_{2}} \ldots X_{i}{ }^{b_{i}} \ldots \ldots X_{n}{ }^{b_{n}} e
$$

Persamaan non-linier tersebut dapat diubah menjadi bentuk linier untuk mempermudah pendugaan terhadap model yang terbentuk, maka persamaan liniernya yaitu:

$$
\begin{gathered}
\operatorname{LnY}=\operatorname{Lna}_{0}+b_{1} \operatorname{Ln} X_{1}+b_{2} \operatorname{Ln} X_{2}+\cdots+b_{n} \operatorname{Ln} X_{n} \\
+\operatorname{Ln} e
\end{gathered}
$$

Selanjutnya dilakukan pengujian secara statistik terhadap fungsi produksi Cobb-Douglas tersebut. Pengujian-pengujian yang dilakukan dalam hal ini adalah pengujian model penduga berupa uji $\mathrm{F}$ dan koefisien determinasi serta pengujian terhadap parameter regresi berupa uji t. Pengolahan data dilakukan dengan menggunakan program SPSS 16.0 dengan metode pembuatan model regresi yaitu metode backward, penggunaan metode ini dikarenakan dalam proses pembentukan modelnya telah mempertimbangkan semua kriteria signifikansi model, meliputi: uji normalitas, multikolinearitas, autokorelasi dan heteroskedastisitas.

\section{(3) Analisis Efisiensi}

Koefisien-koefisien regresi $b_{1}, b_{2}$, $\ldots . . . b_{n}$ dari fungsi produksi CobbDouglas merupakan elastisitas produksi dari variabel input. Besarnya elastisitas produksi (Ep) dapat digunakan untuk mengukur tingkat efisiensi teknis dan efisiensi ekonomis dari penggunaan input variabel. Tingkat efisiensi teknis dalam penggunaan input tercapai bila $\mathrm{Ep}=1$, jika nilai $\mathrm{Ep}<1$ maka penggunaan input tersebut tidak efisien dan jika nilai Ep > 1 maka penggunaan input tersebut tidak efisien. 
Efisiensi ekonomi dapat tercapai jika dapat memaksimumkan keuntungan yaitu menyamakan produk marjinal setiap faktor produksi dengan harganya (Soekartawi, 2003). Menurut Nicholson (1995) efisiensi ekonomi tercapai apabila perbandingan antara nilai produktivitas marginal (NPM) masing-masing input dengan harga inputnya atau biaya korbanan marginal $(\mathrm{BKM})=1$.

$$
\begin{aligned}
& \frac{b \times Y \times P_{y}}{X}=\mathrm{P}_{\mathrm{x}} \\
& \mathrm{NPM}_{\mathrm{xi}}=\frac{\mathrm{b} \times \mathrm{Y} \times \mathrm{P}_{\mathrm{y}}}{\mathrm{x}} \\
& \mathrm{BKM}_{\mathrm{xi}}=\mathrm{P}_{\mathrm{x}} \\
& \mathrm{NPM}_{\mathrm{xi}} / \mathrm{BKM}_{\mathrm{xi}}=1 \\
& \text { imana: } \\
& \mathrm{P}_{\mathrm{x}}=\text { harga faktor produksi atau biaya } \\
& \quad \text { korbanan marginal } \mathrm{x}_{\mathrm{i}}\left(\mathrm{BKM} \mathrm{x}_{\mathrm{i}}\right) \\
& \mathrm{P}=\text { harga produksi } \\
& \mathrm{Y}=\text { produksi } \\
& \mathrm{X}=\text { jumlah faktor produksi } \mathrm{X} \\
& \mathrm{b}=\text { elastisitas produksi }
\end{aligned}
$$$$
\text { Dimana: }
$$

Dalam banyak hal kenyataan $\mathrm{NPM}_{\mathrm{xi}} /$ $\mathrm{BKM}_{\mathrm{xi}}$ tidak selalu sama dengan 1, yang sering terjadi adalah sebagai berikut (Soekartawi, 2003):

a. $\mathrm{NPM}_{\mathrm{xi}} / \mathrm{BKM}_{\mathrm{xi}}>1$; artinya penggunaan input $X$ belum efisien, untuk $m$ encapai efisien input $X$ perlu ditambah.

b. $\mathrm{NPM}_{\mathrm{xi}} / \mathrm{BKM}_{\mathrm{xi}}<1$; artinya penggunaan input $\mathrm{X}$ tidak efisien, untuk mencapai efisien, maka penggunaan input X perlu dikurangi.

\section{HASIL DAN PEMBAHASAN}

\subsection{Hasil Tangkapan dan Daerah Penangkapan}

Target utama pukat cincin adalah kelompok ikan pelagis besar dan pelagis kecil. Hasil tangkapan yang diperoleh alat tangkap pukat cincin selama bulan Januari-Februari 2013 dapat dilihat pada Tabel 1, dimana selama bulan penelitian ada sembilan spesies yang tertangkap oleh armada penangkapan pukat cincin harian.

Jenis hasil tangkapan pukat cincin yang mendominasi selama bulan Januari-Februari 2013 di PPP Lampulo yaitu ikan cakalang sebesar 49.18\%, layang sebesar 20.18 persen, tongkol krai sebesar 8.71 persen dan tuna sebesar 6.17 persen. Beberapa penelitian yang telah dilakukan terkait hasil tangkapan armada penangkapan pukat cincin di
Aceh juga menunjukkan bahwa hasil tangkapan pukat cincin yang dominan yaitu ikan cakalang seperti penelitian yang telah dilakukan oleh Hariati (2011), menunjukkan bahwa jenis-jenis ikan hasil tangkapan pukat cincin di Banda Aceh terdiri atas ikan cakalang sebesar $51.5 \%$, tongkol $31.5 \%$, mandidihang $13.5 \%$ dan diikuti beberapa jenis ikan lainnya.

Distribusi ikan di laut sangat ditentukan oleh berbagai faktor, baik faktor internal dari ikan itu sendiri maupun faktor eksternal dari lingkungan. Faktor lingkungan yaitu berupa parameter oseanografi seperti suhu, salinitas, densitas, oksigen terlarut dan kelimpahan makanan. Komponen-komponen ini akan menentukan keberadaan ikan di lokasi perairan sehingga dapat menjadi petunjuk penentuan fishing ground yang dituju. Perairan di sekitar Pulau Aceh, Pulau Deudab, Pulau Bunta, Pulau Breuh serta perairan Sabang merupakan perairan yang paling banyak dijadikan daerah penangkapan oleh nelayan pukat cincin yang berbasis di PPP Lampulo. Penentuan daerah penangkapan ditentukan oleh pawang kapal dengan melihat kondisi musim ikan dan keadaan cuaca laut pada saat melaut serta berdasarkan pengalaman nelayan yang diwarisi secara turun temurun dalam melakukan penangkapan. Jarak tempuh dari pangkalan (fishing base) yaitu PPP Lampulo ke daerah penangkapan (fishing ground) berkisar antara 25 mil sampai dengan 150 mil dengan waktu tempuh 2-9 jam pelayaran.

Kondisi perairan yang dapat dijadikan arahan dalam penentuan fishing ground dari ikan cakalang sebagai jenis ikan dominan yang tertangkap oleh nelayan pukat cincin yang berbasis di PPP Lampulo yaitu perairan lapisan permukaan dengan suhu $20-30^{\circ} \mathrm{C}$ dan salinitas 31-33 ppm (Mustaruddin, 2011). Ikan ini biasanya hidup bergerombol dan ada juga tertangkap bersama gerombolan ikan lain. Lingkungan perairan utara Aceh dan Pulo Aceh diduga merupakan daerah yang sesuai untuk berkembangnya ikan cakalang. Hal tersebut terlihat dari hasil penelitian yang telah dilakukan oleh muklis et al (2009), yang menyatakan bahwa kondisi perairan Utara Nanggroe Aceh Darussalam berkisar antara $27.00-30.10^{\circ} \mathrm{C}$ dan klorofilnya berkisar antara 0.26-0.33 
$\mathrm{mg} / \mathrm{m}^{3}$. Kisaran suhu dan salinitas di perairan Pulo Aceh yaitu $27.83-30.16^{\circ} \mathrm{C}$ dan 30.20-33.75 ppm (Rizwan et al, 2010).

\subsection{Produktivitas Unit Penangkapan Pukat Cincin}

Hasil tangkapan per unit upaya penangkapan merupakan nilai yang mencerminkan produktivitas armada pukat cincin yang berbasis di PPP Lampulo. Rata-rata produksi, trip, ukuran kapal dan produktivitas selama tahun 20102012 disajikan pada Tabel 2.

Perkembangan produktivitas dari tahun 2010-2012 dapat dilihat pada Tabel 2, selama tiga tahun terakhir produktivitas per trip unit penangkapan pukat cincin harian mengalami peningkatan, produktivitas tertinggi yaitu 1.86 ton/trip pada tahun 2012 dengan jumlah produksi 238.86 ton dan jumlah trip 128.
Seperti yang tertera di Tabel 2 jumlah produksi dan jumlah trip penangkapan pada tahun 2012 merupakan yang terendah dari pada dua tahun sebelumnya. Jumlah trip penangkapan tertinggi yaitu pada tahun 2010 sebesar 155 trip dan jumlah produksi tertinggi yaitu pada tahun 2011 sebesar 241.47 ton. Besarnya trip penangkapan belum tentu menunjukkan besarnya hasil tangkapan yang diperoleh pada tahun tersebut. Hal ini tergantung dari efektifitas dari alat tangkap pukat cincin dalam memperoleh hasil tangkapan, yang ditunjukkan dengan produktivitasnya. Begitupula sebaliknya, produktivitas tidak hanya diukur berdasarkan pada jumlah produksinya saja, tetapi tergantung pula pada jumlah trip penangkapannya (Iriana et al, 2012).

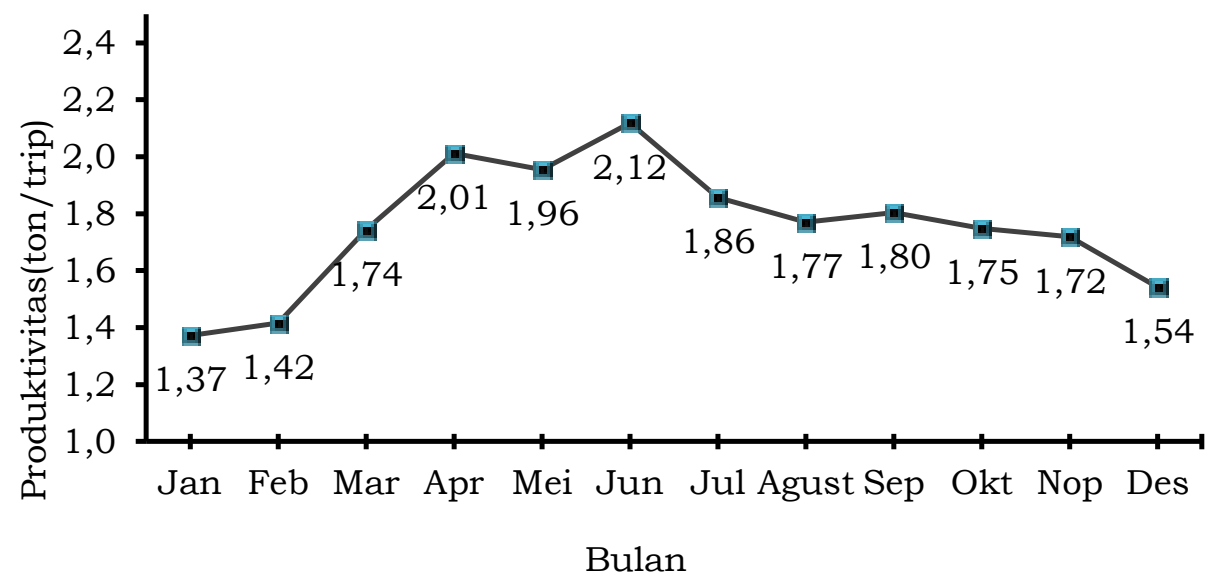

Gambar 1. Perkembangan produktivitas per trip unit penangkapan pukat cincin harian di PPP Lampulo tahun 2012

Tabel 1. Hasil tangkapan pukat cincin selama bulan Januari-Februari 2013

\begin{tabular}{ccc}
\hline \multirow{2}{*}{ Nama Lokal } & \multicolumn{2}{c}{ Komposisi } \\
\cline { 2 - 3 } & $(\mathrm{kg})$ & $(\%)$ \\
\hline Cakalang & 235725 & 49.18 \\
Layang & 96725 & 20.18 \\
Tongkol komo & 20150 & 4.20 \\
Tongkol krai & 41775 & 8.71 \\
Tuna (Yellowfin tuna) & 29555 & 6.17 \\
Salam & 4800 & 1.00 \\
Lemuru & 28525 & 5.95 \\
Kembung & 3650 & 0.76 \\
Selar & 16775 & 3.50 \\
Campuran & 1675 & 0.35 \\
\hline Jumlah & 479355 & 100 \\
\hline
\end{tabular}


Tabel 2. Rata-rata produksi, trip, ukuran kapal dan produktivitas selama tahun 20102012

\begin{tabular}{ccccccc}
\hline Tahun & Unit & Produksi(ton) & Trip & $\begin{array}{c}\text { Ukuran } \\
\text { Kapal } \\
\text { (GT) }\end{array}$ & $\begin{array}{c}\text { Produktivitas } \\
\text { (ton/trip/th) }\end{array}$ & $\begin{array}{c}\text { Produktivitas } \\
\text { (ton/GT/th) }\end{array}$ \\
\hline 2010 & 57 & 239.02 & 155 & 24 & 1.54 & 9.95 \\
2011 & 58 & 241.47 & 132 & 24 & 1.83 & 9.97 \\
2012 & 54 & 238.86 & 128 & 24 & 1.86 & 9.92 \\
\hline
\end{tabular}

Sumber: UPTD PPP Lampulo (2012)

Rata-rata ukuran kapal yang digunakan selama tahun $2010-2012$ yaitu 24 GT. Produktivitas tertinggi terdapat pada tahun 2011 yaitu sebesar 9.97 ton/GT. Hal ini dikarenakan pada tahun tersebut armada penangkapan pukat cincinnya lebih banyak sehingga hasil tangkapan yang diperoleh lebih banyak dari pada hasil tangkapan pada tahun 2010 dan 2012 (nilai produktivitas untuk tahun 2010 yaitu 9.95 ton/GT dan tahun 2012 sebesar 9.92 ton/GT. Hal ini dapat diduga bahwa kapal pukat cincin pada tahun 2011 dapat memanfaatkan secara maksimal kapasitas kapal yang berukuran 24 GT. Besarnya tonnage kapal berhubungan langsung dengan produktivitas dan produksi tangkapan, maka untuk menduga produksi nelayan, disamping didasarkan atas teknologi alat tangkap dan jumlah kapal, juga ditentukan oleh tonnage kapal yang dimiliki (DJPT, 2005). Peningkatan produktivitas sangat terkait dengan kemampuan armada penangkapan, jenis alat tangkap yang digunakan, daerah penangkapan, dan komponen-komponen yang mendukung operasi penangkapan.

Tingkat produktivitas unit penangkapan pukat cincin setiap bulannya pada tahun 2012 dapat dilihat pada Gambar 1 dimana trip penangkapan mengalami fluktuasi. Berfluktuasinya produktivitas pada tahun 2012 sangat dipengaruhi jumlah operasi penangkapan yang dilakukan oleh para nelayan dan hasil tangkapan pukat cincin setiap bulannya di PPP Lampulo. Nilai produktivitas tertinggi adalah 2.12 ton/trip pada bulan Juni dan nilai produktivitas terendah adalah 1.37 ton/trip pada bulan Januari. Atmadja dan Nugroho (2001) dalam Wiyono (2010) menyatakan bahwa nilai produktivitas yang besar menggambarkan stok ikan yang tinggi di suatu perairan. Hal yang serupa juga dinya- takan oleh Sparre dan Venema (1999), dimana nilai yang mencerminkan hasil tangkapan per unit upaya penangkapan atau catch per unit effort (CPUE) merupakan indek kelimpahan stok ikan di perairan.

Berdasarkan hasil wawancara yang dilakukan, musim penangkapan ikan dan biaya perbekalan pada bulan-bulan tertentu mengalami kenaikan, sangat mempengaruhi nelayan untuk tidak melaut. Dari Gambar 1, perkembangan produktivitas/trip unit penangkapan pukat cincin harian di PPP Lampulo tahun 2012 dapat diketahui bahwa musim ikan atau panen ikan jatuh pada bulan April sampai dengan Juli karena pada bulan tersebut rata-rata produksi/tripnya jauh di atas rata-rata produksi/trip selama satu tahun, sedangkan untuk musim paceklik terjadi pada bulan Desember hingga Februari yang rata-rata produksi tripnya jauh dibawah rata-rata produksi per trip selama setahun.

\subsection{Analisis Faktor Produksi}

Hasil tangkapan yang diperoleh nelayan pukat cincin sangat dipengaruhi oleh faktor-faktor produksi usaha perikanan, pada penelitian ini ada 10 variabel yang diteliti untuk melihat signifikansi penggunaannya pada operasi penangkapan ikan. Kesepuluh variabel tersebut yaitu; ukuran kapal $\left(\mathrm{X}_{1}\right)$, dimana ukuran kapal pukat cincin harian yang berbasis di PPP lampulo berkisar 13-30 GT dengan daya mesin kapal $\left(\mathrm{X}_{2}\right)$ 100$180 \mathrm{HP}$, dimensi jaringnya memiliki panjang $\left(\mathrm{X}_{3}\right)$ berkisar 700-1300 $\mathrm{m}$ dan tinggi $\left(\mathrm{X}_{4}\right)$ berkisar $45-72 \mathrm{~m}$, serta alat bantu penangkapan berupa lampu $\left(\mathrm{X}_{7}\right)$ berkisar 7-20 unit. Jumlah awak kapal $\left(\mathrm{X}_{5}\right)$ dalam sekali trip melaut berkisar 1021 orang dengan penggunaan $\mathrm{BBM}\left(\mathrm{X}_{6}\right)$ berkisar 150-400 L, air tawar ( $\left.\mathrm{X}_{9}\right)$ 500- 
$800 \mathrm{~L}$, jumlah es $\left(\mathrm{X}_{8}\right)$ berkisar 5-16 batang, dan biaya perbekalan berkisar Rp.400.000-Rp.780.000. Hasil pengolahan data regresi linier berganda dengan menggunakan program SPSS 16.0 dan metode pembuatan model regresi yaitu metode backward menghasilkan output yang hanya menyisakan prediktor yang signifikan saja, dimana dari 10 variabel hanya menyisakan 5 varibel yang signifikan saja.

Nilai koefisien determinasi $\left(\mathrm{R}^{2}\right)$ untuk model fungsi produksi unit penangkapan pukat cincin harian di PPP Lampulo sebesar 0.727, yang berarti bahwa persentasi sumbangan pengaruh variabel bebas dari daya mesin kapal $\left(\mathrm{X}_{2}\right)$, tinggi jaring $\left(\mathrm{X}_{4}\right)$, jumlah awak kapal $\left(\mathrm{X}_{5}\right)$, jumlah lampu $\left(\mathrm{X}_{7}\right)$, dan biaya perbekalan $\left(\mathrm{X}_{10}\right)$ sebesar 72.7 persen dan sisanya dipengaruhi oleh faktor-faktor lain yang tidak terdapat pada penelitian ini. Faktor lain tersebut misalnya faktor lingkungan atau kondisi daerah penangkapan seperti cuaca, musim penangka- pan, keadaan sumberdaya dan keadaan perairan.

Berdasarkan Tabel 3, nilai $F_{\text {hit }}$ (13.523) lebih besar dari nilai $F_{\text {tab }}(2.055)$ pada tingkat kepercayaan 95 persen, hal ini menunjukkan bahwa pengaruh bersama-sama faktor produksi bersifat signifikan terhadap naik turunnya hasil tangkapan pukat cincin. Selanjutnya untuk analisis secara parsial, maka uji t digunakan sebagai dasar pengambilan keputusan untuk melihat pengaruh masing-masing variabel faktor produksi terhadap hasil tangkapan (Tabel 4). Uji statistik dengan uji t-student untuk mengetahui hubungan masing-masing faktor produksi dengan hasil tangkapan. Berdasarkan Tabel 4, dapat ditulis persamaan fungsi produksi CobbDouglas sebagai berikut:

$\operatorname{LnY}=-18.875-0.432 \operatorname{LnX} 2+0.467$ LnX4 - 1.116 LnX5 - 0.148 LnX7 + 2.181 $\operatorname{LnX} 10\left(\mathrm{R}^{2}=0.727\right)$

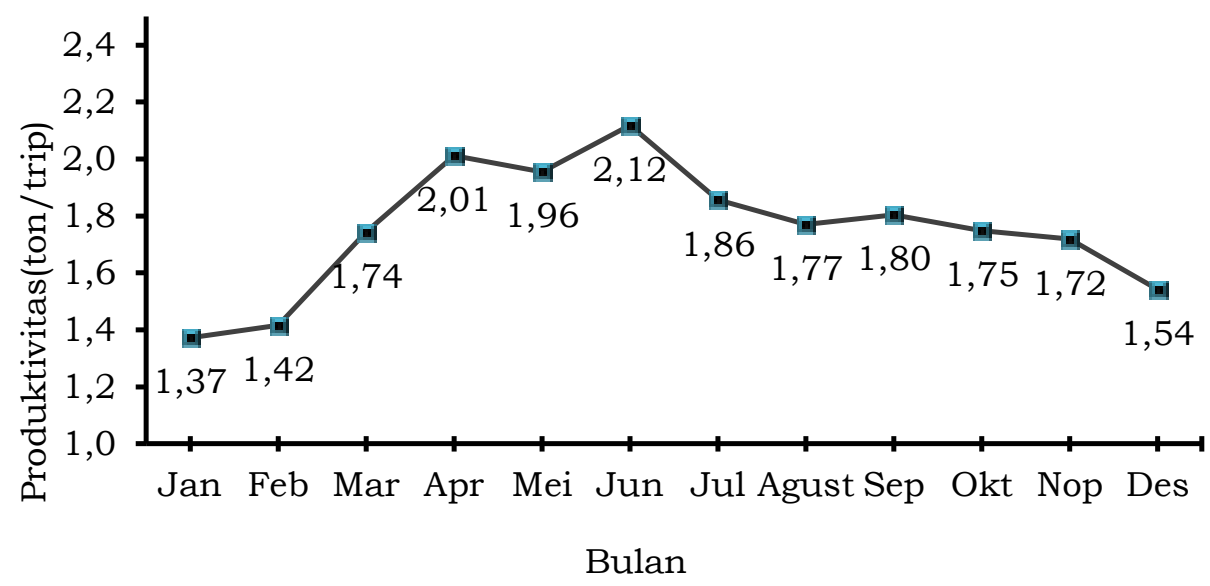

Gambar 1. Perkembangan produktivitas per trip unit penangkapan pukat cincin harian di PPP Lampulo tahun 2012

Tabel 3. Analisis uji koefisien regresi fungsi produksi unit penangkapan pukat cincin

\begin{tabular}{ccccccc}
\hline Sumber & $\mathrm{db}$ & $\begin{array}{c}\text { Jumlah } \\
\text { kuadrat }\end{array}$ & $\begin{array}{c}\text { Rata-rata } \\
\text { Kuadrat }\end{array}$ & Fhit & Ftab & $\mathrm{P}$ \\
\hline Regresi & 5 & 2.48 & 0.496 & 13.523 & 22.055 & 0.000 \\
Residu & 48 & 0.93 & 0.019 & & & \\
Total & 53 & 3.409 & & & & \\
\hline
\end{tabular}


Tabel 4. Nilai koefisien regresi dan uji t fungsi produksi unit penangkapan pukat cincin

\begin{tabular}{|c|c|c|c|c|}
\hline Sumber & $\begin{array}{l}\text { Koefisien } \\
\text { regresi }\end{array}$ & $\begin{array}{c}\text { Standar error } \\
\text { coef }\end{array}$ & $t_{\text {hit }}$ & $\mathrm{P}$ \\
\hline Variabel & -18.875 & 3.826 & -4.933 & 0.000 \\
\hline $\begin{array}{c}\text { Daya mesin } \\
\text { kapal }\end{array}$ & -0.432 & 0.146 & -2.967 & 0.005 \\
\hline Tinggi jaring & 0.467 & 0.162 & 2.882 & 0.006 \\
\hline $\begin{array}{c}\text { Jumlah awak } \\
\text { kapal }\end{array}$ & -1.116 & 0.315 & -3.537 & 0.001 \\
\hline Jumlah lampu & -0.148 & 0.064 & -2.304 & 0.026 \\
\hline Perbekalan & 2.181 & 0.348 & 6.270 & 0.000 \\
\hline
\end{tabular}

Keterangan: ttabel $(0.05)=2.009$

Pada model tersebut terlihat bahwa koefisien variabel tinggi jaring $\left(\mathrm{X}_{4}\right)$ dan biaya perbekalan $\left(\mathrm{X}_{10}\right)$ memberikan tanda positif. Hal ini dapat diartikan bahwa penambahan faktor-faktor produksi tersebut akan mampu meningkatkan produksi yang dihasilkan. Dengan kata lain peningkatan penggunaan tinggi jaring pukat cincin dengan memperhatikan perilaku dari ikan yang menjadi target penangkapan dan kondisi perairan akan meningkatkan hasil tangkapan. Minimum lebar dari jaring dimaksudkan untuk mengikuti kedalaman renang dari gerombolan ikan tersebut (Sudirman dan Mallawa, 2004). Variabel biaya perbekalan $\left(\mathrm{X}_{10}\right)$ juga memberikan peningkatan produksi pukat cincin secara signifikan, dengan dijaminnya persediaan perbekalan tentunya akan memberikan dorongan yang lebih kepada nahkoda dan ABK nya untuk melakukan upaya penangkapan ikan. Berdasarkan hasil wawancara, nelayan menyatakan bahwa semakin terjaminnya semua kebutuhan yang diperlukan kinerja mereka akan lebih optimal sehingga banyak pemilik kapal yang memberikan bonus dan fasilitas yang baik agar mereka dapat bekerja dengan baik dan tidak berpindah ke pemilik kapal lainnya.

Tiga variabel lainnya menghasilkan koefisien regresi yang negatif, yaitu variabel daya mesin kapal $\left(\mathrm{X}_{2}\right)$, jumlah awak kapal $\left(\mathrm{X}_{5}\right)$ dan jumlah lampu $\left(\mathrm{X}_{7}\right)$. Hal ini diduga bahwa penggunaan dari faktor produksi tersebut dalam melakukan penangkapan ikan pada musim barat sudah berlebih, dimana penambahan faktor produksi dari ketiga variabel tersebut akan menurunkan produktivitas penangkapan. Angin ken- cang yang menyebabkan nelayan kesulitan dalam melakukan operasi penangkapan pada akhirnya berpengaruh terhadap hasil tangkapan yang diperoleh nelayan sehingga penambahan dari variabel-variabel itu sendiri tidak akan meningkatkan produksi. Kekuatan mesin yang digunakan harus disesuaikan dengan ukuran kapalnya, penggunaan daya mesin kapal yang tidak sesuai dengan ukuran kapal akan menghambat laju gerak dari kapal itu sendiri. Daya mesin kapal yang digunakan nelayan pukat cincin harian di PPP Lampulo ratarata $128 \mathrm{HP}$ perlu disesuaikan kembali dengan ukuran kapalnya, hal ini terlihat dari koefisien faktor produksi daya mesin kapal yang bernilai negatif pada model fungsi produksi unit penangkapan pukat cincin di PPP Lampulo. Hubungan besarnya ukuran kapal tidak hanya berkaitan terhadap daya mesin kapal yang digunakan, akan tetapi juga terhadap kapasitas awak kapal yang ikut serta dalam setiap trip operasi penangkapan.

Penggunaan jumlah awak kapal setiap trip melaut pada operasi penangkapan pukat cincin di PPP Lampulo ratarata berjumlah 17 orang. Penggunaan tenaga awak kapal diduga sudah optimal sehingga jika terjadi penambahan awak kapal pada operasi penangkapan tidak akan berpengaruh terhadap hasil tangkapan yang diperoleh. Disini yang harus diperhatikan adalah kualitas dari masing-masing tenaga kerja (Sismadi 2006). Dalam memperoleh hasil tangkapan, nelayan pukat cincin menggunakan alat bantu penangkapan berupa lampu. Rata-rata penggunaan lampu pada setiap kapal pukat cincin sebanyak 14 lampu. 
Penggunaan alat bantu penangkapan ini diduga sudah berlebih sehingga apabila terjadi penambahan lampu sekalipun tidak akan berpengaruh terhadap penambahan jumlah hasil tangkapan. Hal yang harus diperhatikan disini adalah intensitas daya lampu yang digunakan, hal demikian diharapkan bahwa penggunaan jumlah lampu dengan daya lampu yang sesuai dapat meningkatkan fungsi lampu sebagai alat bantu penangkapan ikan sehingga dapat berjalan dengan efektif.

\subsection{Efisiensi Teknis dan Ekonomi}

Ditinjau dari segi efisiensi, berdasarkan Tabel 5 efisiensi teknis unit penangkapan pukat cincin di PPP Lampulo untuk faktor produksi daya mesin kapal, jumlah awak kapal dan jumlah lampu nilai elastisitas produksinya sudah negatif $(\mathrm{E} p<0)$ yang menunjukkan penggunaan faktor produksi sudah tidak efisien. Hal ini berarti bahwa telah terjadi penggunaaan faktor produksi yang berlebih oleh kapal-kapal pukat cincin di PPP Lampulo dalam operasi penangkapannya pada musim barat. Penambahan dari penggunaan faktor produksi tersebut dapat mengakibatkan produksi total menurun, untuk mencapai efisiensi dari penggunaan faktor produksi tersebut maka perlu adanya pengurangan penggunaan dari faktor produksi daya mesin kapal, jumlah awak kapal, dan jumlah lampu sehingga dapat efisen dalam memperoleh hasil tangkapan. Pengurangan penggunaan daya mesin kapal yang digunakan dapat disesuaikan dengan ukuran kapalnya, begitu juga dengan jumlah awak kapal dan penggunaan alat bantu penangkapan berupa lampu dikarenakan pada musim barat hasil tangkapan yang diperoleh nelayan pukat cincin cenderung lebih sedikit daripada musim timur sehingga berpengaruh terhadap perolehan pendapatan nelayan, mengingat pendapatan nelayan sangat bergantung pada biaya operasional penangkapan dalam sekali trip melaut dan hasil tangkapan yang diperoleh.

Faktor produksi dari tinggi jaring pukat cincin berada pada tahap produksi rasional karena berada antara $0<\mathrm{Ep}<1$, yang artinya dengan penggunaan faktor produksi tinggi jaring sebesar rata-rata $62 \mathrm{~m}$ yang digunakan nelayan saat melakukan operasi penangkapan ikan pada musim barat sudah sesuai dan seimbang, sehingga dapat memperoleh hasil tangkapan yang maksimal tanpa harus mengurangi atau menambahkan faktor produksi tersebut. Diduga tinggi jaring yang digunakan telah sesuai dengan kondisi perairan setempat dan perilaku dari ikan target, dimana minimum lebar dari jaring dimaksudkan untuk mengikuti kedalaman renang dari gerombolan ikan tersebut (Sudirman dan Mallawa, 2004).

Untuk faktor produksi biaya perbekalan, nilai Ep>1 yang artinya penggunaan faktor produksi belum efisien, dimana perolehan hasil tangkapan dapat lebih ditingkatkan dengan adanya penambahan biaya perbekalan. Dengan kata lain, masih selalu ada kesempatan untuk mengatur kembali kombinasi dan penggunaaan faktor produksi dari biaya perbekalan sedemikian rupa sehingga dapat memperoleh hasil tangkapan lebih besar. Dengan adanya perbekalan yang memadai dapat mendorong kinerja awak kapal semakin optimal, berdasarkan hasil wawancara nelayan menyatakan bahwa semakin terjaminnya semua kebutuhan yang diperlukan maka kinerja mereka akan lebih optimal sehingga banyak pemilik kapal yang memberikan bonus dan fasilitas yang baik agar mereka dapat bekerja dengan baik dan tidak pindah ke pemilik kapal lainnya.

Pada model fungsi produksi CobbDouglas nilai koefisien regresi selain menunjukkan elastisitas dari masingmasing variabel yang bersangkutan, total dari nilai koefisien regresi dari 5 variabel faktor produksi merupakan pendugaan terhadap keadaan skala usaha proses produksi yang sedang berlangsung. Jumlah elastisitas produksi dalam model adalah 0.952, hal ini menunjukkan bahwa tingkat skala usaha berada pada skala deacrising return to scale berarti bahwa proporsi penambahan faktor produksi melebihi proporsi penambahan produksinya. Jika terjadi penambahan faktor produksi maka produksi yang diperoleh tidak akan meningkat, dengan kata lain telah terjadi penggunaan faktor produksi yang berlebih pada proses penangkapan ikan oleh armada penangkapan pukat cincin harian di PPP Lampulo.

Secara ekonomis, efisiensi akan tercapai pada kondisi dimana harga sama dengan nilai produk marginalnya. 
Jika harga dari setiap faktor produksi ke$\mathrm{i}\left(\mathrm{P}_{\mathrm{xi}}\right)$ adalah biaya korbanan marginalnya (BKM) dan produk marginal dikalikan dengan tingkat harga hasil tangkapan (Y) adalah nilai produk marginal (NPM), maka kondisi efisiensi ekonomis tercapai pada $\mathrm{NPM}_{\mathrm{xi}}=\mathrm{BKM}_{\mathrm{xi}}$. Penelitian dilakukan selama bulan Januari-Februari 2013, dimana pada bulan tersebut merupakan musim barat. Harga ikan dipasaran pada bulan tersebut melambung tinggi dikarenakan sedikitnya ikan yang tertangkap dan dijual dipasaran. Produksi rata-rata yang diperoleh nelayan sebesar $716 \mathrm{~kg}$ per trip dengan harga jual hasil tangkapan Rp 35000 per kilogram, permintaan pasar yang tinggi menyebabkan harga jual ikan di pasar juga tinggi. Harga jual ikan yang tinggi tidak menjamin efisiensi ekonomi dari penggunaan faktor produksi usaha perikanan tersebut.

Berdasarkan Tabel 5 dapat dilihat bahwa penggunaan faktor-faktor produksi unit penangkapan pukat cincin di PPP Lampulo berada dalam kondisi tidak efisien secara ekonomi, dimana nilai NPM/BKM lebih kecil dari satu. Perlu adanya peninjauan ulang dari penggunaan faktor-faktor produksi tersebut pada musim barat sehingga dapat meminimkan biaya operasional penangkapan dan tercapainya efisiensi ekonomi dari penggunaan faktor produksi tersebut. Penggunaan kelima faktor produksi tersebut pada level efisiennya tidak dapat diramalkan secara tepat, dikarenakan secara teori apabila nilai NPM negatif, maka NPMxi/BKMxi negatif sehingga syarat keharusan untuk mencapai level efisien dalam penggunaan faktor produksi tidak terpenuhi.

Tidak tercapainya efisiensi secara ekonomi dalam penggunaan faktor produksi tersebut menyebabkan kecenderungan para nelayan pukat cincin harian di PPP Lampulo tidak melakukan penangkapan. Berdasarkan hasil wawancara, banyak dari nelayan pukat cincin harian pada musim barat hanya melakukan perbaikan armada penangkapan dan alat tangkap pukat cincin. Nelayan tidak mau mengambil resiko melaut dikarenakan angin yang kencang dan gelombang perairan yang tidak stabil sehingga tidak dapat mencapai daerah penangkapan ikan yang dituju, mereka hanya melakukan penangkapan tidak jauh dari pantai. Sebagian dari kapalkapal pukat cincin yang berukuran besar lebih memilih bertambat di dermaga menunggu kondisi perairan stabil kembali. Kondisi ini menuntut nelayan lebih cermat dalam penggunaan faktor produksi usaha perikanan yang berpengaruh terhadap hasil tangkapan yang di peroleh sehingga tercapainya efisiensi secara ekonomi. Hal lainnya yang mempengaruhi tingkat efisiensi ekonomi disini selain karena ketersediaan sumberdaya ikan yang minim pada musim barat, juga dikarenakan nelayan tidak dapat menjangkau daerah penangkapan yang lebih jauh, nelayan hanya melakukan operasi penangkapan dekat dengan pantai, dan biaya faktor produksi penangkapan yang mengalami kenaikan harga sehingga menekan biaya operasional penangkapan.

Pencapaian efisiensi secara keseluruhan dapat terjadi apabila kualitas nelayan dapat ditingkatkan terkait penguasaan teknologi yang mampu memberikan pedoman yang jelas mengenai keberadaan kelompok ikan diperairan. Kemampuan pengelolaan biaya operasional penangkapan juga sangat berpengaruh sehingga mampu mengalokasikan sumberdaya ikan yang ada secara efektif dan efisien yang akhirnya diperoleh hasil produksi yang maksimal.

Tabel 5. Efisiensi teknis unit penangkapan pukat cincin di PPP Lampulo

\begin{tabular}{llll}
\hline No & Variabel & Rata-rata & $\mathrm{Ep}$ \\
\hline 1 & Daya mesin kapal & $128 \mathrm{HP}$ & -0.432 \\
2 & Tinggi jaring pukat cincin & $62 \mathrm{~m}$ & 0.467 \\
3 & Jumlah awak kapal & 17 orang & -1.116 \\
4 & Jumlah lampu & 14 unit & -0.148 \\
5 & Perbekalan & 626 666 Rupiah & 2.181 \\
\hline
\end{tabular}


Tabel 6. Rasio NPM dan BKM dari Produksi Unit Penangkapan Pukat Cincin di PPP Lampulo

\begin{tabular}{lrrr}
\hline Faktor Produksi & \multicolumn{1}{c}{ NPM } & \multicolumn{1}{c}{ BKM } & \multicolumn{1}{c}{ NPM/BKM } \\
\hline Daya mesin kapal & -72869.78 & 30000000 & $-2.819 \times 10^{-03}$ \\
Tinggi jaring pukat cincin & 183099.68 & 238000000 & $7.931 \times 10^{-04}$ \\
Jumlah Awak Kapal & -1207302.35 & 1500000 & -1.09 \\
Jumlah Lampu & -329.36 & 1800000 & -0.147 \\
Perbekalan & 84.86 & 750000 & $1.162 \times 10^{-04}$ \\
\hline
\end{tabular}

Keterangan:

NPM = Nilai Produk Marjinal

$\mathrm{BKM}=$ Biaya Korbanan Marjinal

\section{KESIMPULAN DAN SARAN}

\subsection{Kesimpulan}

Berdasarkan hasil dan pembahasan dalam penelitian ini dapat disimpulkan sebagai berikut:

1. Produktivitas per trip tertinggi yaitu sebesar 1.86 ton/trip pada tahun 2012 dan produktivitas per GT tertinggi yaitu 9.97 ton/GT pada tahun 2011, hal ini menunjukkan efektifitas dari upaya penangkapan berupa trip penangkapan dan ukuran kapal yang dilakukan nelayan pukat cincin harian di PPP Lampulo dalam memperoleh hasil tangkapan pada tahun tersebut sangat baik.

2. Faktor produksi unit penangkapan pukat cincin harian yang berpengaruh nyata terhadap hasil tangkapan pada musim barat yaitu daya mesin kapal, tinggi jaring, awak kapal, jumlah lampu dan perbekalan.

3. Analisis efisiensi teknis pada 54 kapal menunjukkan penggunaan variabel faktor produksi daya mesin kapal (0.432), jumlah awak kapal (-1.116), dan jumlah lampu (-0.184) sudah tidak efisien, faktor produksi tinggi jaring (0.467) berada pada tahap produksi rasional dimana penggunaannya sudah sesuai. Sedangkan penggunaan faktor produksi biaya perbekalan (2.181) belum efisien. Secara efisiensi ekonomis, penggunaan variabel faktor produksi usaha perikanan pukat cincin harian pada musim barat tidak efisien (NPMxi/ BKMxi<1).

\subsection{Saran}

Dari kesimpulan di atas dapat diajukan saran supaya pengelolaan usa- ha perikanan pukat cincin harian di PPP Lampulo lebih optimal yaitu:

1. Kegiatan penangkapan pukat cincin harian perlu disesuaikan dengan karakteristik kapal yang digunakan agar tepat sasaran dalam memanfaatkan sumberdaya ikan yang ada.

2. Penggunaan faktor produksi daya mesin kapal, jumlah awak kapal dan jumlah lampu yang digunakan dalam setiap trip penangkapan perlu dikurangi dari kondisi saat penelitian sehingga efisiensi penangkapan akan menjadi lebih baik.

3. Perlu adanya penelitian lanjutan efisiensi unit penangkapan pukat cincin harian pada musim yang berbeda (musim timur) sehingga perbedaan tingkat efisiensi penggunaan faktor produksi dapat diketahui.

\section{DAFTAR PUSTAKA}

[DKP] Dinas Kelautan dan Perikanan Provinsi Aceh. 2012. Statistik Perikanan Tangkap Provinsi Aceh. Banda Aceh.

[DJPT] Direktorat Jenderal Perikanan Tangkap. 2005. Petunjuk Pelaksanaan Pengukuran Volume Palkah Kapal Perikanan. Direktorat Kapal Perikanan dan Alat Penangkap Ikan. Jakarta.

Hariati T. 2011. Status dan Perkembangan Perikanan Pukat Cincin di Banda Aceh. Jurnal Penelitian Perikanan Indonesia. 17(3): 157167.

Iriana D, Kahan AM, Rostika R, Simpati S, Sunarto. 2012. Efektivitas alat tangkap ikan lemuru di kabupaten Kotabaru, Kalimantan Selatan. Depik. 1(3): 131-135. 
McCluske SM, Lewinson RL. 2008. Quantifying Fishing Effort: a synthesis of current methods and their applications. Fish and fisheries. No 9: 188-200.

Muklis, Gaol JL, Simbolon D. 2009. Pemetaan Daerah Potensial Penangkapan Ikan Cakalang (Katsuwonus pelamis) dan Tongkol (Euthynnus affinis) di Perairan Utara Nanggroe Aceh Darussalam. Jurnal Ilmu dan Teknologi Kelautan Tropis. 1(1): 2432.

Mustaruddin. 2011. Arahan Pemanfaatan Sumberdaya Ikan Berdasarkan Aspek Lingkungan dan Teknis di Kawasan Konservasi Laut. - Buku II New Paradigm in Marine Fisheries: Pemanfaatan dan Pengelolaan Sumberdaya Perikanan Laut Berkelanjutan. Tri WN, Domu S, Akhmad S, Shinta Y, editor. Bogor: Departemen Sumber Daya Perikanan.

Nicholson W. 1995. Teori Mikro Ekonomi, Prinsip Dasar dan Perluasan. Bina Rupa Aksara. Jakarta.

Rizwan, Purnawan S, Miswar E. 2010. Study of Oceanography and Fisheries in Pulo Aceh Waters. Jurnal Natural. 10(2): 35-42.
Sismadi. 2006. Analisis Efisiensi Penggunaan Input Alat Tangkap Purse Seine di Kota Pekalongan. [Tesis]. Semarang (ID). Universitas Diponegoro.

Soekartawi. 2003. Teori Ekonomi Produksi. Dengan Pokok Bahasan Analisis Fungsi Cobb-Douglas. Raja Grafindo Persada. Jakarta.

Sparre P, Venema SC. 1999. Introduksi Pengkajian Stok Ikan Tropis. Jakarta (ID): Pusat Penelitian dan Pengembangan Perikanan.

Sudirman, Mallawa A. 2004. Teknik Penangkapan Ikan. Jakarta: Rineka Cipta.

Sugiyono. 2007. Statistika untuk Penelitian. CV Alfabeta. Bandung.

[UPTD] Unit Pelaksanaan Teknis Dinas Pelabuhan Perikanan Lampulo. 2012. Laporan Tahunan UPTD Pelabuhan Perikanan Lampulo Tahun 2011 [Laporan Tahunan]. Banda Aceh.

Wiyono ES. 2010. Komposisi, Diversitas dan Produktivitas Sumberdaya Ikan Dasar di Perairan Pantai Cirebon, Jawa Barat. Jurnal Ilmu Kelautan. 15(4):214-220. 